\title{
Effect of caustic treatment on cotton/modal blended fabric
}

DOI: $10.35530 / I T .071 .05 .1726$

BILAL ZAHID

MUHAMMAD ZUBAIR

MUHAMMAD ALI

MEHMOOD KARIM

\section{ABSTRACT - REZUMAT}

\section{Effect of caustic treatment on cotton/modal blended fabric}

Attempt has been made to assess the cotton/modal (60:40) blended woven fabric properties after mercerization with caustic lye of different strengths. Cotton/Modal (60:40) fabric was subjected to bulk mercerization process and subsequently dyed with reactive dyes. The colour strength, fastness properties (washing, staining and rubbing etc.), tensile and tear strength and shrinkage were characterized. The results of this study indicate that cotton/modal blended fabric that was considered in this study can be processed under similar conditions as those that are maintained for cotton fabrics generally and that the aforementioned properties are improved generally.

Keywords: Modal, mercerization, colour strength, fastness properties, tear \& tensile strength

Influența tratamentului cu sodă caustică asupra materialelor textile din amestec fibros de bumbac/fibre modale

S-a încercat evaluarea proprietăților țesăturii din amestec fibros de bumbac/fibre modale (60:40), după mercerizare cu soluţie alcalină de sodă caustică de diferite concentrații. Țesătura de bumbac/fibre modale (60:40) a fost supusă unui proces industrial de mercerizare și apoi de vopsire cu coloranți reactivi. Au fost determinate proprietățile de intensitate și rezistență a culorii (modificarea culorii la spălare, cedarea culorii și rezistenţa la frecare etc.), rezistența la tracțiune și la sfâșiere și contracția la spălare. Rezultatele au indicat faptul că țesătura în amestec fibros de bumbac/fibre modale luată în studiu poate fi prelucrată în condiții similare cu cele utilizate uzual pentru țesăturile din bumbac, iar proprietățile menționate anterior sunt în general îmbunătătite.

Cuvinte-cheie: fibre modale, mercerizare, intensitatea culorii, rezistența culorii, rezistența la sfâșiere și la tracțiune

\section{INTRODUCTION}

By the mid of the $20^{\text {th }}$ century, synthetic fibers including nylon, polyester and acrylics had witnessed a growth so rapid that the production of cotton has had to be cut back by legislation in the USA, for instance. This extra-ordinary growth in the demand of synthetic fibers can be attributed to a number of factors including reduced raw material costs, series of breakthroughs in the chemical industry, developments in plant operations and arguably the most attractive option of a greater control on the fiber properties. The aforementioned and other advantages of using synthetic fibers in textiles also proved to be the driving force for continued growth in the production and utilization of regenerated fibers. In the case of regenerated fibers, the advantage of being able to use abundantly available natural raw materials for their production, has over the years, proved to be a consistent factor in maintaining the status of such fibers as a feasible option for use in textiles [1].

Despite all the excitement regarding the man-made fibers and their world wide acceptance, it is an established fact that there is role is to supplement not to supplant the natural fibers [2]. Thus, blending of synthetic fibers as well as regenerated fibers with natural fibers has been practiced for decades now and for most combinations that are worthy of making end products, the resulting benefits in terms of the characteristics of the end product are well known [3-8]. Depending upon the ratio in which a natural fiber is mixed with one or more man-made fibers, the potential benefits may include, but are not limited to, reduced overall costs, improved thermal characteristics [9], comfort properties [10], changes in abrasion and pilling performance, improved dimensional stability and shrinkage control, etc. [11].

Among the natural fibers that are used in textiles, cotton continues to be a fiber of first choice for a broad range of applications; from apparels to home textiles. Due to the advantages mentioned in the preceding text, blends of cotton with other man-made fibers are widely studied and abundant literature is available regarding the characterization of such blends [12, 13]. Arguably, the most widely studied is the cottonpolyester blend [14-17]. Among the class of regenerated fibers, viscose has gained wide spread acceptance primarily due to considerably lower production cost and the fact that it can be spun very uniform in diameter. Some of the inferior properties of viscose in comparison to cotton, for instance, low wet strength, high elongation and dimensional instability, etc. have been dealt with by different approaches ranging from new methods of spinning to resin finishing [18].

As greater control over the viscose process was achieved, several varieties of regenerated cellulosic 
fibers were produced to achieve specific characteristics that the earlier varieties lacked in some respects, for instance, low wet modulus [19]. "Modal" is a widely used generic term for regenerated cellulosic fibers obtained by processes giving a high tenacity and a high wet modulus. It is defined by the international bureau for standardization of manmade fibers (BISFA) as a distinct rayon fiber genre which has a higher wet modulus and satisfies a minimum value of tenacity in the wet stage at $5 \%$ elongation. Lenzing AG of austria is a leader in the development and marketing of modal fiber. Their first modal fiber was marketed under the tradename Hochmodul 333 and in the 1990s they introduced the very first micromodal ${ }^{\circledR}$. Further developments in the manufacturing process have rendered certain varieties of modal twice as soft as cotton. More importantly, the softness lasts longer and is able to withstand repeated wash and dry cycles. In addition, superior mechanical properties, e.g., higher tenacity profile than viscose, and other advantages are resulting in an ever increasing use of modal in blended form with other fibers [20, 21]. Blends of modal and cotton fibers are generally pretreated as pure cotton i.e. Boiled off, bleached and if necessary, also mercerized. The chemicals added to the boiling and bleaching phases are reduced correspondingly depending on the proportion of modal fiber [22].

As for all other fibers, the general properties of modal are thoroughly discussed in a number of studies [23-25]. The literature regarding production-scale processing and its effects on the properties is rather limited to the dyeing behaviour of blends of modal $[22,26]$. In this work, we present our findings regarding the effects production-scale processes on the properties of 60:40 cotton/modal woven fabric. In particular, the effects of caustic treatment using different strengths of caustic soda have been discussed in the context of colour strength achieved in dyeing, fastness properties, hand feel, breaking strength and shrinkage properties. Due to the high swelling propensity of modal fibers in lye of a higher concentration, lensing special guidelines have been drawn up for mercerizing cotton/modal blends particularly with respect to fabric construction and machine dynamics. These guidelines provide the basic framework for this study.

\section{MATERIALS \& METHODS}

\section{Substrate}

Cotton/Modal (60:40) blended yarn was prepared and converted into woven fabric. Some of the more important fabric specifications are provided in table 1.

\section{Pre-treatment of fabric}

Pretreatment of fabric was carried out on bulk, continuous processing machines. The recipes and process parameters of the various pretreatment operations are provided in tables 2-4. The primary aim of the present study was to analyse the effects of caustic treatment on the properties of modal/cotton blended

\begin{tabular}{|l|c|}
\hline \multicolumn{2}{|c|}{\begin{tabular}{c} 
Table 1 \\
\multicolumn{2}{|c|}{} \\
SPECIFICATIONS OF THE FABRIC USED \\
IN THE STUDY
\end{tabular}} \\
\hline Warp yarn count & $60: 40$ \\
\hline Weft yarn count & $60 \mathrm{~s}$ \\
\hline Weave & $40 \mathrm{~s}$ \\
\hline Ends/inch & $4: 1$ Sateen \\
\hline Picks/inch & 178 \\
\hline Thread count & 122 \\
\hline GSM & 300 \\
\hline
\end{tabular}

fabric. Thus, caustic treatment of the substrates that were pretreated in exactly the same manner was carried out using three different strengths of caustic as mentioned in table 4.

Table 2

COMBINED SINGEING AND DESIZING PROCESS

\begin{tabular}{|l|c|}
\hline \multicolumn{2}{|c|}{ Singeing } \\
\hline Machine name & Oshthoff Senge \\
\hline Machine speed & $95 \mathrm{~m} / \mathrm{min}$ \\
\hline Number of burners & 4 \\
\hline \multicolumn{2}{|c|}{ Desizing } \\
\hline Machine name & Singeing Oshthoff \\
\hline Batch/Dwell time & 6 hours \\
\hline Liqour temperature & $70^{\circ} \mathrm{C}$ \\
\hline Liqour pH & 7 \\
\hline Enzymatic sesizer & $0.5 \mathrm{~g} / \mathrm{l}$ \\
\hline Wetting agent & $3 \mathrm{~g} / \mathrm{l}$ \\
\hline
\end{tabular}

Table 3

\begin{tabular}{|l|c|}
\hline \multicolumn{2}{|c|}{ BLEACHING PROCESS OF FABRIC } \\
\hline \multicolumn{2}{|c|}{ Bleaching Recipe } \\
\hline Hydrogen peroxide & $24 \mathrm{~g} / \mathrm{l}$ \\
\hline $\mathrm{NaOH}(50 \%)$ & $20 \mathrm{~g} / \mathrm{l}$ \\
\hline Wetting agent & $3 \mathrm{~g} / \mathrm{l}$ \\
\hline Sequestering agent: & $1 \mathrm{~g} / \mathrm{l}$ \\
\hline Stabilizer Bleaching Process Parameters \\
\hline \multicolumn{2}{|c|}{ gat/ } \\
\hline Pre-washing temperature & $95^{\circ} \mathrm{C}$ \\
\hline No. of chambers (pre-wash) & 3 \\
\hline Machine speed & $100 \mathrm{~m} / \mathrm{min}$ \\
\hline Steamer time & $22 \mathrm{~min}$ \\
\hline Wetting agent & $3 \mathrm{~g} / \mathrm{l}$ \\
\hline Post washing temperature & $95^{\circ} \mathrm{C}$ \\
\hline No. of chambers (post-wash) & 4 \\
\hline
\end{tabular}

\section{Dyeing of fabric}

Reactive dyes $\left(\right.$ Jakazo $\left.^{\circledR}\right)$ in powder form were used for dyeing of samples. All other chemicals used in this 
CAUSTIC TREATMENT OF FABRIC USING THREE DIFFERENT STRENGTHS OF $\mathrm{NaOH}$

\begin{tabular}{|l|c|}
\hline Machine name & Benninger \\
\hline Machine speed & $55 \mathrm{~m} / \mathrm{min}$ \\
\hline \multirow{3}{*}{ Strong lye concentration } & $7 \mathrm{Be}^{\circ}$ \\
& $20 \mathrm{Be}^{\circ}$ \\
& $28 \mathrm{Be}^{\circ}$ \\
\hline Weak lye concentration & $7 \mathrm{Be}^{\circ}$ \\
\hline Temperature of strong lye & $60^{\circ} \mathrm{C}$ \\
\hline Post washing chamber & 4 \\
\hline Temperature & $95^{\circ} \mathrm{C}$ \\
\hline Neutralization chamber & $60^{\circ} \mathrm{C}$ \\
\hline
\end{tabular}

work were of analytical grade. Dyeing was carried out on production scale machines and the pad-dry-chemical pad-steam route was followed. The process and machine parameters maintained for all samples are provided in table 5 and table 6 , respectively.

Table 5

\begin{tabular}{|l|c|}
\hline \multicolumn{2}{|c|}{ DYEING PROCESS DETAIL } \\
\hline Dyeing recipe & $\begin{array}{c}\text { Jakofix Yellow MERL } 8.9 \mathrm{~g} / \mathrm{l}, \\
\text { Jakazol Navy DSG } 13.43 \mathrm{~g} / \mathrm{l}, \\
\text { Jakazol Black CECL-N } 47.39 \mathrm{~g} / \mathrm{l}\end{array}$ \\
\hline Dyeing machine & Thermosol Continuous Range \\
\hline Dyeing pick up & $65 \%$ \\
\hline Pre drying & IR dryers \\
\hline Drying temp & $120^{\circ} \mathrm{C}$ \\
\hline Speed of machine & $60 \mathrm{~m} / \mathrm{min}$ \\
\hline
\end{tabular}

Table 6

\begin{tabular}{|l|c|}
\hline \multicolumn{2}{|c|}{ CHEMICAL PAD STEAM PROCESS } \\
\hline Chemical Padding & Salt, Alkali, Urea \\
\hline Steaming Temp & $103^{\circ} \mathrm{C}$ \\
\hline Steaming Time & $90 \mathrm{~s}$ \\
\hline Post Washing & 9 chambers \\
\hline Post Washing Temp & $95^{\circ} \mathrm{C}$ \\
\hline Speed & $\mathrm{m} / \mathrm{min}$ \\
\hline
\end{tabular}

\section{ANALYSIS OF THE TREATED FABRICS}

$\mathrm{K} / \mathrm{S}$ analysis of dyed fabric samples

Colorimetric analysis of reactive dyed fabrics was carried out using a Datacolor SF 600 plus spectrophotometer. Measurement were taken regarding colour presence, brightness, dullness and colour intensity with the specular component of the light excluded and UV component included using illuminant D65 and $10^{\circ}$ standard observer. Each fabric was folded once so as to furnish two layers in front of the aperture. The values reported here are the average of five readings that were taken.

\section{Fastness tests}

The samples were washed under condition IIIA of according to AATCC Test Method 61-2006 (2003) to determine the colour change. Light fastness tests were carried out according to AATCC Test Method 16 E-1998 (2003). The samples were exposed to 5 and 10 AFUs (AATCC Fading Unit) to determine the colour change. Standard crock meter was used to determine the rubbing fastness of dyed fabrics under wet and dry condition to assess the colour change and staining property according to the test method AATCC 08-1996 (2005).

\section{Dimensional stability}

Some superior physical properties of modal such as tenacity, elongation and wet modulus make a fabric last longer with an enduring look and feel. However, in the case of blends of Modal with other fibers, the blend ratio and the treatment conditions are of course expected to have a direct effect on the overall dimensions stability of the fabric. Thus, in the context of the present study, it was considered to be important to characterize the dimensional stability of the Cotton/ Modal blended fabrics that were considered. For this purpose, dimensional stability of the test samples was tested according to ISO $6330(4 \mathrm{~N})$ at $40^{\circ} \mathrm{C}$ (Tumble Dry).

\section{Breaking strength analysis}

Owing to similar reasons as mentioned in Section 3.3 , the samples were tested for tensile strength in warp and weft directions according to ISO 13934-2 (grab method). Tear strength was tested in warp and weft using ISO 13937-1 (Elmendorf tester). For each fabric average of five readings were recorded.

\section{RESULTS \& DISCUSSION}

\section{Colorimetric strength of samples}

The results tabulated in table 7 clearly indicate that the $\mathrm{K} / \mathrm{S}$ value increased with increasing lye concentration. This trend is expected in the case of cellulosic fibers and their blends and it is attributed to the formation of soda-cellulose and increased intra-fibrillar swelling. This phenomenon can be explained through Donnan's membrane theory. In its simplistic form, it elucidates that cellulose reacts with $\mathrm{NaOH}$ to form soda cellulose (Cell-O-Na+) and ionization of this

Table 7

\begin{tabular}{|c|c|c|c|c|c|c|c|}
\hline \multicolumn{10}{|c|}{ COLORIMETRIC DATA FOR DYED SAMPLES } \\
\hline Sample & $\begin{array}{c}\text { Caustic } \\
\text { strength } \\
\left(\mathbf{B e}^{\circ}\right)\end{array}$ & L & A & b & C & h & K/S \\
\hline A & 7 & 21.03 & -1.61 & -2.16 & 2.70 & 233.31 & $98.07 \%$ \\
\hline B & 20 & 21.56 & -1.55 & -2.39 & 2.85 & 236.91 & $104.52 \%$ \\
\hline C & 28 & 19.82 & -1 & -2.29 & 2.50 & 246.41 & $118.09 \%$ \\
\hline
\end{tabular}


compound creates a high concentration of sodium ions within the fiber. Under this concentration gradient water molecules diffuse through the cuticular semi-permeable membrane of the fiber and so cause swelling of the fiber.

\section{Colour fastness testing}

The results of washing tests are provided in table 8 . It is evident from this data that there was no recordable difference between the fabric samples in terms of shade change after washing and as well as in terms of staining. Furthermore, the grey scale rating of 4 and $4-4.5$ for shade change and staining, respectively, indicate that the Cotton/Modal blended fabrics treated with caustic of various strengths possessed very good colour fastness properties. Similarly, the rubbing fastness test results (table 9) also indicate that treatment of the blended fabric with caustic of various strengths did not result in a significant difference between the samples in terms of their colour fastness to rubbing.

Table 8

\begin{tabular}{|c|c|c|c|c|}
\hline \multicolumn{5}{|c|}{ WASHING FASTNESS TEST RESULTS } \\
\hline \multirow[b]{2}{*}{ Sample } & \multirow{2}{*}{$\begin{array}{c}\text { Caustic } \\
\text { strength } \\
\left(\mathrm{Be}^{\circ}\right)\end{array}$} & \multicolumn{3}{|c|}{ Grey scale rating } \\
\hline & & $\begin{array}{l}\text { Shade } \\
\text { change }\end{array}$ & $\begin{array}{l}\text { Staining } \\
\text { on cotton }\end{array}$ & $\begin{array}{l}\text { Staining } \\
\text { on nylon }\end{array}$ \\
\hline A & 7 & 4.0 & 4.0 & 4.5 \\
\hline$B$ & 20 & 4.0 & 4.0 & 4.5 \\
\hline C & 28 & 4.0 & 4.0 & 4.5 \\
\hline
\end{tabular}

Table 9

\begin{tabular}{|c|c|c|c|}
\hline \multicolumn{4}{|c|}{ RUBBING FASTNESS TEST RESULTS } \\
\hline \multirow{2}{*}{ Sample } & $\begin{array}{c}\text { Caustic } \\
\text { strength }\left(B^{\circ}{ }^{\circ}\right)\end{array}$ & Rubbing Fastness \\
\cline { 3 - 4 } & 7 & 4 & Wet \\
\hline A & 20 & 4 & 2.5 \\
\hline B & 28 & 4 & 2.5 \\
\hline C & & & 2.5 \\
\hline
\end{tabular}

\section{Fabric strength testing}

The results of tensile and tear strength in the weft and warp directions are provided in table 10. A clear trend of increasing tensile and tear strength with increasing lye concentration is observed in all cases. It is noteworthy that increasing lye concentration from $20 \mathrm{Be}^{\circ}$ to $28 \mathrm{Be}^{\circ}$ resulted in well over $10 \%$ increase in the tear strength of fabric. Furthermore, this trend

Table 10

\begin{tabular}{|c|c|c|c|c|c|}
\hline \multicolumn{6}{|c|}{ TENSILE AND TEAR STRENGTH RESULTS } \\
\hline Sample & $\begin{array}{c}\text { Caustic } \\
\text { strength } \\
\left(\mathbf{B e}^{\circ}\right)\end{array}$ & \multicolumn{2}{|c|}{ Tensile (Kg) } & \multicolumn{2}{c|}{ Tear (gf) } \\
\cline { 3 - 6 } & 7 & 17.5 & 20 & 888.5 & 1100 \\
\hline A & 7 & Weft & Warp & Weft \\
\hline B & 20 & 22 & 21 & 932 & 1123 \\
\hline C & 28 & 23 & 21.5 & 1082 & 1243 \\
\hline
\end{tabular}

is consistent with that observed in the case of mercerization of a $100 \%$ cotton fabric. It is known for this type of treatment to result in increased orientation of the molecular chains in the amorphous regions of fiber. In addition, parallelization of crystallites on stretching increases the secondary interactions between the molecular chains. Removal of inherent strains in the fiber after their relaxation on swelling also helps in improving the overall strength of fiber.

\section{Dimensional stability/shrinkage}

The results of shrinkage tests on the samples that were treated with caustic lye of different strengths are provided in table 11 . The results clearly show that the dimensional stability is improved with increasing caustic lye strength. This can be attributed to improved dimensional stability of the cotton component in the blend. However, it also indicates that there is no considerable deterioration in the shrinkagerelated properties of the modal component in the blended fabric.

Table 11

WARP-WISE AND WEFT-WISE SHRINKAGE OF SAMPLES

\begin{tabular}{|c|c|c|c|}
\hline \multirow{2}{*}{ Sample } & \multirow{2}{*}{$\begin{array}{c}\text { Caustic } \\
\text { Strength }\left(\mathrm{Be}^{\circ}\right)\end{array}$} & \multicolumn{2}{|c|}{ Shrinkage } \\
\cline { 3 - 4 } & 7 & Warp & Weft \\
\hline A & 20 & $-4.0 \%$ & $-4.0 \%$ \\
\hline B & 28 & $-3.0 \%$ & $-3.0 \%$ \\
\hline C & $28.5 \%$ \\
\hline
\end{tabular}

\section{CONCLUSIONS}

From the results obtained in this study, it can be concluded that mercerization of $60: 40$ Cotton/Modal (60:40) blend can be carried out under conditions and parameters that are normally maintained for $100 \%$ cotton fabrics. Colorimetric data for the samples treated with caustic lye of different strengths shows that treatment with $28 \mathrm{Be}^{\circ}$ caustic lye results in improved dyeing characteristics. Furthermore, the tensile and tear strength and the dimensional stability of the particular blend that was considered in this study were also improved after treatment with $28 \mathrm{Be}^{\circ}$ caustic lye. A potential extension of the reported research is to test different blend ratios and subject those samples to caustic treatment in a similar way as reported in the present study. In this way, it can be studied if caustic treatment affects different blend ratios differently or otherwise. Owing to the fact that the treatments on the cotton/modal blended fabric were carried out on production-scale machinery, it is envisaged that the present study will prove to be a helpful guideline for the concerned textile processors.

\section{ACKNOLEDGEMENTS}

The authors would like to thank Sheikh Idrees Bashir (R\&D Manager, Lucky Textile Mills, Karachi) and Muhammad Moosa Rehman (Incharge Knits Processing, Lucky Textile Mills, Karachi) for the support they provided in the conduct of this study. The authors would also like to acknowledge NED University, Karachi for the moral support throughout this study. 


\section{REFERENCES}

[1] Bredereck, K., Hermanutz F., Man-made cellulosics, 2005, 35, 1, 59-75

[2] Maria, M.T., Malgorzata, M., Jorge, B.B., Future of Natural Fibers, Their Coexistence and Competition with Man-Made Fibers in 21st Century AU - Ryszard M., Kozlowski, In: Molecular Crystals and Liquid Crystals, 2012, $556,1,200-222$

[3] Atkinson, R.R., The Blending of Jute with Man-Made Fibres. The Effect Of Various Blending Methods upon Some Yarn and Fabric Properties Au - Cumming, In: Journal of the Textile Institute Proceedings, 1963, 54, 2, P92-P100

[4] Hunter, W.A., Fibre Blending, In: Journal of the Textile Institute Proceedings, 1952, 43, 8, P365-P374

[5] Leach, L.L., Blends Containing the New Man-Made Fibers AU - Dennison, R.W., In: Journal of the Textile Institute Proceedings, 1952, 43, 8, P473-P495

[6] Monego, C.J., Backer, S., Tensile Rupture of Blended Yams, 1968, 38, 7, 762-766

[7] Owen, J.D., 51 - The Strength and Behaviour of Nylon/Cotton Blended Yarns Undergoing Strain AU - Kemp, A., In: Journal of the Textile Institute Transactions, 1955, 46, 11, T684-T698

[8] Ratnam, T.V., et al., Prediction of the Quality of Blended Yarns from That of the Individual Components, 1968, 38, 4, 360-365

[9] Majumdar, A., Mukhopadhyay, S., Yadav, R., Thermal properties of knitted fabrics made from cotton and regenerated bamboo cellulosic fibres, In: International Journal of Thermal Sciences, 2010, 49, 10, 2042-2048

[10] Hosseini Ravandi, S.A., Valizadeh, M., 2 - Properties of fibers and fabrics that contribute to human comfort, in Improving Comfort in Clothing, Editor Song G., 2011, Woodhead Publishing, 61-78

[11] Ramaswamy, G.N., Easter, E.P., Durability and Aesthetic Properties of Kenaf/Cotton Blend Fabrics, 1997, 67, 11, 803-808

[12] Ibrahim, N.A., 4 - Dyeing of textile fibre blends, in Handbook of Textile and Industrial Dyeing, Editor Clark M., 2011, Woodhead Publishing, 147-172

[13] Stanković, S.B., Popović, D., Poparić, G.B., Thermal properties of textile fabrics made of natural and regenerated cellulose fibers, In: Polymer Testing, 2008, 27, 1, 41-48

[14] Alongi, J., et al., Thermal stability and flame retardancy of polyester, cotton, and relative blend textile fabrics subjected to sol-gel treatments, 2011, 119, 4, 1961-1969

[15] Ruppenicker, G.F., et al., Comparison of Cotton/Polyester Core and Staple Blend Yarns and Fabrics, 1989, 59, 1, 12-17

[16] van Winkle, T.L., et al., Cotton versus Polyester: Surprising facts on energy requirements for the production and maintenance of clothing made of these two kinds of fibers suggest priorities for the utilization of energy and land, In: American Scientist, 1978, 66, 3, 280-290

[17] Yoon, H.N., Buckley, A., Improved Comfort Polyester: Part I: Transport Properties and Thermal Comfort of Polyester/Cotton Blend Fabrics, 1984, 54, 5, 289-298

[18] Lund, G.V., The Blending of Viscose Rayon and Other Fibres With Particular Reference to the Cotton System of Processing, AU - Morton, W.E., In: Journal of the Textile Institute Proceedings, 1952, 43, 8, P375-P390

[19] Shaikh, T., Chaudhari, S., Varma, A., Viscose Rayon: A legendary development in the manmade textile, In: International Journal of Engineering Research \& Applcation, 2012, 2, 5, 675-680

[20] Gun, A.D.J.F., Polymers, Dimensional, physical and thermal properties of plain knitted fabrics made from 50/50 blend of modal viscose fiber in microfiber form with cotton fiber, 2011, 12, 8, 1083-1090

[21] Latif, W., et al., Study of mechanical and comfort properties of modal with cotton and regenerated fibers blended woven fabrics, In: Journal of Natural Fibers, 2018, 1-10

[22] Radhika, R., Moses, J.J., Study on dyed and finished modal, cotton and modal/cotton (50:50) blend fabrics for their color strength and fastness properties, In: International Journal of Engineering Research and Science \& Technology, 2014, 3, 2

[23] Suñol, J., et al., Thermal degradation of lyocell, modal and viscose fibers under aggressive conditions, 2007, 87, $1,41-44$

[24] Suńol, J., et al., Comparison of the thermal behavior of three cellulose fibers mercerized or submitted to solar degradation, 2003, 72, 2, 753-758

[25] Zengqiang, Z., Guiyang, L., Relation between Modal Cotton Blended Yarn Property and Blending Ratio, In: Clothing Textile Technology, 2005, 11

[26] Hasan-Al Mamun, et al., Effect of Reactive Groups of Reactive Dyes on Dyeing of Modal Fabrics, In: International Journal of Textile Science, 2017, 6, 6, 158-164

\section{Authors:}

BILAL ZAHID ${ }^{1}$, MUHAMMAD ALI ${ }^{1}$, MUHAMMAD ZUBAIR², KAREEM MEHMOOD ${ }^{3}$

${ }^{1}$ NED University, Department of Textile Engineering, University Road, 75270, Karachi, Pakistan

${ }^{2}$ North Caroline State University, College of Textiles, Raleigh, USA

e-mail: zubair@ncsu.edu

${ }^{3}$ Lucky Textile Mills, Landhi Industrial Area, Karachi, Pakistan

Corresponding author:

MUHAMMAD ALI

e-mail: alimughal@neduet.edu.pk 